\title{
Shewanella marisflavi sp. nov. and Shewanella aquimarina sp. nov., slightly halophilic organisms isolated from sea water of the Yellow Sea in Korea
}

Correspondence

Jung-Hoon Yoon

jhyoon@kribb.re.kr

\author{
Jung-Hoon Yoon, ${ }^{1}$ Soo-Hwan Yeo, ${ }^{2}$ In-Gi Kim ${ }^{1}$ and Tae-Kwang Oh ${ }^{1}$ \\ ${ }^{1}$ Korea Research Institute of Bioscience and Biotechnology (KRIBB), PO Box 115, Yusong, \\ Taejon, Korea \\ ${ }^{2}$ The Center for Traditional Microorganism Resources, Keimyung University, Shindang-Dong, \\ Dalseo-gu, Daegu, Korea
}

Two Gram-negative, motile, non-spore-forming, rod-shaped organisms, strains SW-117 and $\mathrm{SW}-120^{\top}$, were isolated from sea water of the Yellow Sea in Korea and subjected to a polyphasic taxonomic study. Strains $\mathrm{SW}-117^{\top}$ and $\mathrm{SW}-120^{\top}$ simultaneously contained both menaquinones (MK) and ubiquinones $(\mathrm{Q})$ as isoprenoid quinones; the predominant menaquinone was MK-7 and the predominant ubiquinones were Q-7 and Q-8. The major fatty acid detected in the two strains was iso- $C_{15: 0}$. The DNA G $+C$ content of strains $S W-117^{\top}$ and $S W-120^{\top}$ was 51 and $54 \mathrm{~mol} \%$, respectively. Phylogenetic analyses based on 16S rRNA gene sequences showed that strains $\mathrm{SW}-117^{\top}$ and $\mathrm{SW}-120^{\top}$ fall within the radiation of the cluster comprising Shewanella species. Strains $\mathrm{SW}-117^{\top}$ and $\mathrm{SW}-120^{\top}$ showed a $16 \mathrm{~S}$ rRNA gene sequence similarity of $97 \cdot 4 \%$ and a DNA-DNA relatedness level of $10 \cdot 1 \%$. Strains SW-117 ${ }^{\top}$ and $S W-120^{\top}$ exhibited 16S rRNA gene sequence similarity levels of $93 \cdot 8-98 \cdot 5 \%$ and $92 \cdot 4-97 \cdot 0 \%$, respectively, to Shewanella species. Strain SW $-117^{\top}$ exhibited DNA-DNA relatedness levels of $8 \cdot 3-20 \cdot 3 \%$ to the type strains of six phylogenetically related Shewanella species. On the basis of phenotypic, phylogenetic and genetic data, strains $S W-117^{\top}$ and $S W-120^{\top}$ were classified in the genus Shewanella as two distinct novel species, for which the names Shewanella marisflavi sp. nov. (type strain, SW $-117^{\top}=\mathrm{KCCM} 41822^{\top}=\mathrm{JCM} 12192^{\top}$ ) and Shewanella aquimarina sp. nov. (type strain, SW $-120^{\top}=\mathrm{KCCM} 41821^{\top}=\mathrm{JCM} 12193^{\top}$ ) are proposed, respectively.
The genus Shewanella was created by MacDonell \& Colwell (1985) with two species that had been assigned to the genus Alteromonas, Alteromonas putrefaciens and Alteromonas hanedai. Subsequently, many Shewanella species have been isolated from a variety of sources, including aquatic and marine environments (Nealson et al., 1991; Ivanova et al., 2001; Bozal et al., 2002), clinical samples (Nozue et al., 1992; Brink et al., 1995; Venkateswaran et al., 1999), sediments (Myers \& Nealson, 1988), oilfield fluids (Semple \& Westlake, 1987) and others. The genus Shewanella is phylogenetically affiliated to the $\gamma$-Proteobacteria

Published online ahead of print on 17 September 2004 as DOI 10.1099/ijs.0.63198-0.

The GenBank/EMBL/DDBJ accession numbers for the 16S rRNA gene sequences of strains SW- $117^{\top}$ and $S W-120^{\top}$ and Shewanella colwelliana ATCC $39565^{\top}$ are AY485224, AY485225 and AY653177, respectively.

Detailed phenotypic characteristics of Shewanella marisflavi, Shewanella aquimarina and related species, and an expanded neighbour-joining tree are available as supplementary material in IJSEM Online.
(Anzai et al., 2000). There are at least 25 recognized Shewanella species at the time of writing. In this study, we describe two Gram-negative, slightly halophilic, rod-shaped organisms, strains $\mathrm{SW}-117^{\mathrm{T}}$ and $\mathrm{SW}-120^{\mathrm{T}}$, which were isolated from sea water of the Yellow Sea in Korea. From $16 \mathrm{~S}$ rRNA gene sequence comparisons, these organisms were considered to be phylogenetically related to the genus Shewanella. Accordingly, the aim of the present work was to establish the taxonomic positions of strains $\mathrm{SW}-117^{\mathrm{T}}$ and $\mathrm{SW}-120^{\mathrm{T}}$ by using a combination of polyphasic taxonomic data.

Strains $\mathrm{SW}-117^{\mathrm{T}}$ and $\mathrm{SW}-120^{\mathrm{T}}$ were isolated by a standard dilution plating technique on marine agar 2216 (MA; Difco) at $30^{\circ} \mathrm{C}$. Shewanella marinintestina JCM $11558^{\mathrm{T}}$, Shewanella sairae JCM $11563^{\mathrm{T}}$ and Shewanella schlegeliana JCM $11561^{\mathrm{T}}$ were obtained from the Japan Collection of Microorganisms (JCM), Saitama, Japan. Shewanella affinis KMM $3587^{\mathrm{T}}$ and Shewanella waksmanii KMM $3823^{\mathrm{T}}$ were obtained from Professor Elena P. Ivanova, Industrial Research Institute, Swinburne University of Technology, Australia. Shewanella colwelliana ATCC $39565^{\mathrm{T}}$ was obtained 
from the American Type Culture Collection (ATCC), Manassas, USA. Cell biomass of strains SW $-117^{\mathrm{T}}$ and SW$120^{\mathrm{T}}$ for respiratory lipoquinone analysis and for DNA extraction was obtained from cultivation in marine broth 2216 (MB; Difco) at $30^{\circ} \mathrm{C}$. For fatty acid methyl ester (FAME) analysis, cell mass of strains SW- $117^{\mathrm{T}}$ and SW$120^{\mathrm{T}}$ was obtained from agar plates after cultivation for 2 days at $30^{\circ} \mathrm{C}$ on $\mathrm{MA}$ and trypticase soy agar (TSA; Difco). Cell morphology was examined by light microscopy (Nikon E600) and transmission electron microscopy (TEM). Flagellum type was examined by TEM using cells from exponentially growing cultures. Gram reaction was determined using a Gram Strain kit (bioMérieux) according to the manufacturer's instructions. The $\mathrm{pH}$ range for growth was determined in $\mathrm{MB}$ that was adjusted to various $\mathrm{pH}$ values ( $\mathrm{pH} 4 \cdot 5-9 \cdot 0$ at intervals of $0 \cdot 5 \mathrm{pH}$ units). Growth at various $\mathrm{NaCl}$ concentrations was investigated in $\mathrm{MB}$ or trypticase soy broth (Difco). Growth in the absence of $\mathrm{NaCl}$ was investigated in trypticase soy broth without $\mathrm{NaCl}$. Growth at various temperatures $\left(4-50{ }^{\circ} \mathrm{C}\right)$ was measured on MA. Growth under anaerobic conditions was determined after incubation in an anaerobic chamber on anaerobically prepared MA. Catalase activity was determined by bubble production in a $3 \%(\mathrm{v} / \mathrm{v})$ hydrogen peroxide solution. Oxidase activity was determined by oxidation of $1 \%(\mathrm{w} / \mathrm{v})$ p-aminodimethylaniline oxalate. Hydrolysis of casein, starch and Tween 80 was determined as described by Cowan \& Steel (1965). Hydrolysis of hypoxanthine, tyrosine and xanthine was performed on MA using substrate concentrations described by Cowan \& Steel (1965). Hydrolysis of gelatin and aesculin and nitrate reduction were determined as described by Lanyi (1987) with a modification

Table 1. Phenotypic characteristics of Shewanella marisflavi sp. nov., Shewanella aquimarina sp. nov. and related Shewanella species

Species: 1, S. marisflavi; 2, S. aquimarina; 3, S. affinis, data from Ivanova et al. (2004); 4, S. colwelliana, data from Weiner et al. (1988) and Ivanova et al. (2004); 5, S. waksmanii, data from Ivanova et al. (2003b). +, Positive reaction; -, negative reaction; v, variable reaction; ND, not determined; $n$, number of strains. All species are rod-shaped, Gram-negative and polarly flagellated. All species are positive for growth in $3 \% \mathrm{NaCl}$, catalase, oxidase and gelatinase. All species are negative for utilization of D-fructose, glycerol, lactose and sucrose.

\begin{tabular}{|c|c|c|c|c|c|}
\hline Characteristic & $1(n=1)$ & $2(n=1)$ & $3(n=4)$ & $4(n=1)$ & $5(n=1)$ \\
\hline Optimal $\mathrm{pH}$ for growth & $7-8$ & $7-8$ & ND & $7 \cdot 4-7 \cdot 8$ & $7 \cdot 5$ \\
\hline Optimal temperature for growth $\left({ }^{\circ} \mathrm{C}\right)$ & $30-37$ & $30-37$ & $20-25$ & 25 & $2-25$ \\
\hline Maximum temperature for growth $\left({ }^{\circ} \mathrm{C}\right)$ & 42 & 42 & 34 & 30 & 30 \\
\hline \multicolumn{6}{|l|}{ Growth at: } \\
\hline $4^{\circ} \mathrm{C}$ & + & - & - & - & + \\
\hline $35^{\circ} \mathrm{C}$ & + & + & - & - & - \\
\hline $40{ }^{\circ} \mathrm{C}$ & + & + & - & - & - \\
\hline $\mathrm{NO}_{3}$ to $\mathrm{NO}_{2}$ & + & + & + & + & ND \\
\hline $\mathrm{NO}_{2}$ to $\mathrm{N}_{2}$ & - & - & - & $\mathrm{ND}$ & $\mathrm{ND}$ \\
\hline Haemolysis & + & + & + & ND & + \\
\hline $\mathrm{H}_{2} \mathrm{~S}$ production & + & + & + & ND & $\mathrm{ND}$ \\
\hline \multicolumn{6}{|l|}{ Production of: } \\
\hline Amylase & - & + & - & + & - \\
\hline Lipase & + & + & + & ND & + \\
\hline \multicolumn{6}{|l|}{ Growth at: } \\
\hline $0 \% \mathrm{NaCl}$ & + & - & - & - & - \\
\hline $6 \% \mathrm{NaCl}$ & + & + & + & - & + \\
\hline $8 \% \mathrm{NaCl}$ & + & + & $\mathrm{V}$ & - & - \\
\hline \multicolumn{6}{|l|}{ Utilization of: } \\
\hline D-Galactose & - & + & - & - & - \\
\hline Maltose & + & + & ND & - & ND \\
\hline Succinate & + & + & - & - & - \\
\hline Fumarate & - & - & - & + & - \\
\hline Citrate & - & - & + & - & - \\
\hline D-Mannitol & - & - & + & - & ND \\
\hline D-Sorbitol & - & - & ND & - & ND \\
\hline DL-Malate & + & + & ND & - & $\mathrm{ND}$ \\
\hline DL-Lactate & + & + & + & - & - \\
\hline DNA G $+\mathrm{C}$ content $(\mathrm{mol} \%)$ & 51 & 54 & 45 & 46 & 43 \\
\hline
\end{tabular}


that artificial sea water was used. The artificial sea water contained (per litre of distilled water) $23.6 \mathrm{~g} \mathrm{NaCl}, 0.64 \mathrm{~g}$ $\mathrm{KCl}, 4.53 \mathrm{~g} \mathrm{MgCl}_{2} \cdot 6 \mathrm{H}_{2} \mathrm{O}, 5.94 \mathrm{~g} \mathrm{MgSO}_{4} \cdot 7 \mathrm{H}_{2} \mathrm{O}$ and $1.3 \mathrm{~g}$ $\mathrm{CaCl}_{2} \cdot 2 \mathrm{H}_{2} \mathrm{O}$ (Levring, 1946). Hydrolysis of birchwood xylan (Sigma) was determined on solid marine salts basal medium (Baumann \& Baumann, 1981) containing 0.5\% (w/v) xylan as the sole carbon source. $\mathrm{H}_{2} \mathrm{~S}$ production was tested as described by Bruns et al. (2001). Haemolytic activity was recorded on MA with $5 \%$ defibrinated sheep blood. Enzyme activity was determined using the API ZYM system (bioMérieux). Acid production from carbohydrates was determined as described by Leifson (1963). Utilization of substrates as sole carbon and energy sources was tested as described by Baumann \& Baumann (1981).

Isoprenoid quinones were extracted and analysed as described by Komagata \& Suzuki (1987) using reversed-phase HPLC. For quantitative analysis of the cellular fatty acid compositions, a loop of cell mass was harvested and FAMEs were extracted and prepared according to the standard protocol of the MIDI/Hewlett Packard Microbial Identification System (Sasser, 1990). Chromosomal DNA was isolated and purified according to the method described by Yoon et al. (1996), except that ribonuclease T1 was used with ribonuclease A. The DNA G $+\mathrm{C}$ content was determined by the method of Tamaoka \& Komagata (1984). DNA was hydrolysed and the resultant nucleotides were analysed by reversed-phase HPLC. The $16 \mathrm{~S}$ rRNA gene was amplified by PCR using two universal primers as described by Yoon et al. (1998). Sequencing of the amplified $16 \mathrm{~S}$ rRNA gene and phylogenetic analysis were performed as described by Yoon et al. (2003). DNA-DNA hybridization was performed fluorometrically by the method of Ezaki et al. (1989) using photobiotin-labelled DNA probes and microdilution wells. Hybridization was performed with five replications for each sample. The highest and lowest values obtained for each sample were excluded; reported DNA-DNA relatedness values are the mean of the remaining three values.

Morphological, cultural, physiological and biochemical characteristics of strains $\mathrm{SW}-117^{\mathrm{T}}$ and $\mathrm{SW}-120^{\mathrm{T}}$ are shown in Table 1 or are given in the species descriptions below. Strain $\mathrm{SW}-117^{\mathrm{T}}$ grew at $4{ }^{\circ} \mathrm{C}$ and without $\mathrm{NaCl}$, but strain SW $-120^{\mathrm{T}}$ did not. Starch was hydrolysed by strain SW$120^{\mathrm{T}}$, but not by strain SW-117 ${ }^{\mathrm{T}}$. D-Galactose was utilized by strain $\mathrm{SW}-120^{\mathrm{T}}$, but not by strain $\mathrm{SW}-117^{\mathrm{T}}$. Acid from D-glucose, D-cellobiose and maltose was produced by strain $\mathrm{SW}-117^{\mathrm{T}}$, but not by strain $\mathrm{SW}-120^{\mathrm{T}}$. Strains SW$117^{\mathrm{T}}$ and $\mathrm{SW}-120^{\mathrm{T}}$ contained simultaneously both menaquinones (MK) and ubiquinones (Q) as isoprenoid quinones. The predominant ubiquinones detected in strain $\mathrm{SW}-117^{\mathrm{T}}$ were Q-7 and Q-8 at a peak area ratio of about 49 and $48 \%$, respectively, and the predominant ubiquinones detected in strain SW-120 $0^{\mathrm{T}}$ were Q-7 $(67 \%)$ and Q-8 (31\%). The two strains contained MK-7 as the predominant menaquinone (about 92 and $86 \%$, respectively). Strains $\mathrm{SW}-117^{\mathrm{T}}$ and $\mathrm{SW}-120^{\mathrm{T}}$ had cellular fatty acid profiles that contained large amounts of straightchain, branched, unsaturated and hydroxy fatty acids (Table 2). There were differences in the proportions of some fatty acids when the two strains were grown on MA and TSA (Table 2). Strains SW- $117^{\mathrm{T}}$ and SW- $-120^{\mathrm{T}}$ contained iso- $\mathrm{C}_{15: 0}$, iso- $\mathrm{C}_{15: 0} 2-\mathrm{OH}$ and/or $\mathrm{C}_{16: 1} \omega 7 \mathrm{c}$ and $\mathrm{C}_{16: 0}$ as the major fatty acids when they were grown on MA (Table 2). The proportions of iso- $\mathrm{C}_{15: 0} 2-\mathrm{OH}$ and/or $\mathrm{C}_{16: 1} \omega 07 c$ and $\mathrm{C}_{16: 0}$ decreased when the two strains were grown on TSA (Table 2). The proportions of some fatty acids, for example iso- $\mathrm{C}_{13: 0}$, iso- $\mathrm{C}_{17: 0}$ and iso- $\mathrm{C}_{13: 0} 3-\mathrm{OH}$, increased when the strains were grown on TSA (Table 2). The DNA G + C contents of strains SW $-117^{\mathrm{T}}$ and SW $-120^{\mathrm{T}}$ were 51 and $54 \mathrm{~mol} \%$, respectively, values higher than those

Table 2. Percentage cellular fatty acid composition of strains $\mathrm{SW}-117^{\top}$ and $\mathrm{SW}-120^{\top}$ on marine agar (MA) and trypticase soy agar (TSA)

\begin{tabular}{|c|c|c|c|c|}
\hline \multirow[t]{2}{*}{ Fatty acid ${ }^{\star}$} & \multicolumn{2}{|c|}{$S W-117^{T}$} & \multicolumn{2}{|c|}{$S W-120^{T}$} \\
\hline & MA & TSA & MA & TSA \\
\hline \multicolumn{5}{|c|}{ Straight-chain fatty acid } \\
\hline $\mathrm{C}_{12: 0}$ & $1 \cdot 6$ & $0 \cdot 6$ & $1 \cdot 9$ & $0 \cdot 6$ \\
\hline $\mathrm{C}_{13: 0}$ & $0 \cdot 5$ & $0 \cdot 4$ & $0 \cdot 9$ & $0 \cdot 4$ \\
\hline $\mathrm{C}_{14: 0}$ & $1 \cdot 5$ & $0 \cdot 31$ & $1 \cdot 3$ & $0 \cdot 2$ \\
\hline $\mathrm{C}_{15: 0}$ & $4 \cdot 1$ & $3 \cdot 1$ & $4 \cdot 4$ & $1 \cdot 6$ \\
\hline$C_{16: 0}$ & $14 \cdot 5$ & $4 \cdot 1$ & $11 \cdot 6$ & $2 \cdot 3$ \\
\hline $\mathrm{C}_{17: 0}$ & $1 \cdot 9$ & $1 \cdot 8$ & $1 \cdot 7$ & $0 \cdot 8$ \\
\hline \multicolumn{5}{|c|}{ Branched fatty acid } \\
\hline iso- $\mathrm{C}_{11: 0}$ & $2 \cdot 0$ & $4 \cdot 8$ & $0 \cdot 1$ & $0 \cdot 2$ \\
\hline iso- $\mathrm{C}_{13: 0}$ & $5 \cdot 9$ & $9 \cdot 9$ & $7 \cdot 4$ & $13 \cdot 7$ \\
\hline iso- $\mathrm{C}_{14: 0}$ & $0 \cdot 7$ & $0 \cdot 6$ & $0 \cdot 9$ & $1 \cdot 1$ \\
\hline iso- $\mathrm{C}_{15: 0}$ & $22 \cdot 9$ & $30 \cdot 9$ & $27 \cdot 5$ & $34 \cdot 9$ \\
\hline iso- $\mathrm{C}_{16: 0}$ & $0 \cdot 2$ & $0 \cdot 6$ & $0 \cdot 4$ & $1 \cdot 3$ \\
\hline iso- $\mathrm{C}_{17: 0}$ & $1 \cdot 6$ & $6 \cdot 0$ & $1 \cdot 9$ & $9 \cdot 9$ \\
\hline \multicolumn{5}{|c|}{ Unsaturated fatty acid } \\
\hline $\mathrm{C}_{16: 1} \omega 9 c$ & $0 \cdot 7$ & $0 \cdot 3$ & $0 \cdot 7$ & $0 \cdot 3$ \\
\hline $\mathrm{C}_{17: 1} \omega 6 c$ & $0 \cdot 6$ & $0 \cdot 9$ & $0 \cdot 8$ & $1 \cdot 0$ \\
\hline $\mathrm{C}_{17: 1} \omega 8 c$ & $5 \cdot 3$ & $9 \cdot 5$ & $6 \cdot 7$ & $7 \cdot 8$ \\
\hline $\mathrm{C}_{18: 1} \omega 7 c$ & $4 \cdot 1$ & $2 \cdot 9$ & $3 \cdot 4$ & $2 \cdot 3$ \\
\hline $\mathrm{C}_{18: 1} \omega 9 c$ & $1 \cdot 7$ & $1 \cdot 2$ & $1 \cdot 6$ & $0 \cdot 9$ \\
\hline \multicolumn{5}{|c|}{ Hydroxy fatty acid } \\
\hline $\mathrm{C}_{12: 0} 3-\mathrm{OH}$ & $1 \cdot 3$ & $0 \cdot 7$ & $0 \cdot 8$ & $0 \cdot 2$ \\
\hline iso- $\mathrm{C}_{13: 0} 3-\mathrm{OH}$ & $4 \cdot 5$ & $11 \cdot 3$ & $5 \cdot 1$ & $10 \cdot 9$ \\
\hline \multicolumn{5}{|c|}{ Summed features $\dagger$} \\
\hline 1 & $0 \cdot 5$ & $0 \cdot 7$ & $0 \cdot 6$ & $0 \cdot 3$ \\
\hline 2 & $0 \cdot 9$ & $0 \cdot 3$ & $0 \cdot 9$ & $0 \cdot 2$ \\
\hline 3 & $18 \cdot 6$ & $5 \cdot 7$ & $15 \cdot 9$ & $6 \cdot 0$ \\
\hline
\end{tabular}

${ }^{*}$ Fatty acids representing less than $0.5 \%$ in all rows were omitted. $\dagger$ Summed features represent groups of two or three fatty acids that could not be separated by GLC with the MIDI system. Summed feature 1 contained one or more of $\mathrm{C}_{13: 0} 3-\mathrm{OH}$ and/or iso- $\mathrm{C}_{15: 1}$. Summed feature 2 contained one or more of iso- $\mathrm{C}_{16: 1} \mathrm{I}$ and/or $\mathrm{C}_{14: 0}$ 3-OH. Summed feature 3 contained one or more of $\mathrm{C}_{16: 1} \omega 7 c$ and/or iso- $\mathrm{C}_{15: 0} 2-\mathrm{OH}$. 
of most Shewanella species (Table S1, supplementary table in IJSEM Online).

Almost-complete 16S rRNA gene sequences of strains SW $-117^{\mathrm{T}}$ and $\mathrm{SW}-120^{\mathrm{T}}$ comprising, respectively, 1500 and 1499 nt (about $96 \%$ of the Escherichia coli 16S rRNA gene sequence) were determined in this study. Phylogenetic analysis based on $16 \mathrm{~S}$ rRNA gene sequences showed that strains $\mathrm{SW}-117^{\mathrm{T}}$ and $\mathrm{SW}-120^{\mathrm{T}}$ fall within the radiation of the cluster comprising Shewanella species. In a phylogenetic tree based on the neighbour-joining algorithm, strains SW $-117^{\mathrm{T}}$ and SW- $120^{\mathrm{T}}$ occupied independent evolutionary lineages within the phylogenetic radiation encompassed by the genus Shewanella, particularly within the clade comprising Shewanella affinis, S. colwelliana, S. waksmanii, S. marinintestina, S. sairae, S. schlegeliana, S. pealeana, S. gelidimarina, S. benthica, S. violacea, S. hanedai, S. woodyi, S. fidelis, S. amazonensis and S. algae (Fig. 1). The relationship between this clade and the cluster comprising other Shewanella species was supported by a high bootstrap confidence level of $99 \cdot 9 \%$ (Fig. 1). The level of $16 \mathrm{~S}$ rRNA gene sequence similarity between strains $\mathrm{SW}-117^{\mathrm{T}}$ and SW $-120^{\mathrm{T}}$ was $97 \cdot 4 \%$. Strains $\mathrm{SW}-117^{\mathrm{T}}$ and $\mathrm{SW}-120^{\mathrm{T}}$ exhibited highest $16 \mathrm{~S}$ rRNA gene sequence similarity values to S. affinis $\mathrm{KMM} 3587^{\mathrm{T}}$ and S. colwelliana ATCC $39565^{\mathrm{T}}(98.5 \%$, respectively) and S. waksmanii $\mathrm{KMM}$ $3823^{\mathrm{T}}(97 \cdot 0 \%)$ (Fig. 1). Strains SW- $117^{\mathrm{T}}$ and SW- $120^{\mathrm{T}}$ exhibited 16S rRNA gene sequence similarity levels of 93.8-97.9 and $92 \cdot 4-96.9 \%$, respectively, to the type strains of the other recognized Shewanella species. Levels of $16 \mathrm{~S}$ rRNA gene sequence similarity between strains $\mathrm{SW}-117^{\mathrm{T}}$ and $\mathrm{SW}-120^{\mathrm{T}}$ and other species used in the phylogenetic analysis were lower than $91.9 \%$ (Fig. 1). DNA-DNA hybridization was performed to determine the genetic relatedness between strains SW- $117^{\mathrm{T}}$ and SW$120^{\mathrm{T}}$, between strain $\mathrm{SW}-120^{\mathrm{T}}$ and the type strains of three Shewanella species, and between strain SW- $117^{\mathrm{T}}$ and the type strains of six Shewanella species that showed 16S rRNA gene sequence similarity levels of more than $97 \%$ to strain $\mathrm{SW}-117^{\mathrm{T}}$. Strains $\mathrm{SW}-117^{\mathrm{T}}$ and $\mathrm{SW}-120^{\mathrm{T}}$ exhibited mean DNA-DNA relatedness of $10 \cdot 1 \%$, when their DNAs were used individually as labelled DNA probes for cross-hybridization. This value indicates that strains SW $-117^{\mathrm{T}}$ and SW $-120^{\mathrm{T}}$ are members of different genomic species. Strain SW-117 ${ }^{\mathrm{T}}$ exhibited DNA-DNA relatedness levels of $8 \cdot 3-20 \cdot 3 \%$ to S. affinis KMM $3587^{\mathrm{T}}$, S. colwelliana ATCC $39565^{\mathrm{T}}$, S. waksmanii KMM $3823^{\mathrm{T}}$, S. marinintestina JCM $11558^{\mathrm{T}}$, S. sairae JCM $11563^{\mathrm{T}}$ and S. schlegeliana JCM $11561^{\mathrm{T}}$. Strain SW $-120^{\mathrm{T}}$ exhibited DNA-DNA relatedness levels of $6 \cdot 3-13 \cdot 7 \%$ to S. affinis KMM $3587^{\mathrm{T}}$, S. colwelliana ATCC $39565^{\mathrm{T}}$ and S. waksmanii $\mathrm{KMM} 3823^{\mathrm{T}}$.

$16 \mathrm{~S}$ rRNA gene sequence analysis revealed that strains SW$117^{\mathrm{T}}$ and SW-120 ${ }^{\mathrm{T}}$ have closest phylogenetic affiliations to the $\gamma$-Proteobacteria, particularly to the genus Shewanella (Fig. 1). The results obtained in chemotaxonomic analyses are consistent with the results of $16 \mathrm{~S}$ rRNA gene sequence analysis and phylogenetic inference. The cellular fatty acid profiles of the two strains are similar to those of recognized Shewanella species, although there are some differences in the proportions of the major fatty acids (Bowman et al., 1997; Venkateswaran et al., 1999; Bozal et al., 2002; Ivanova

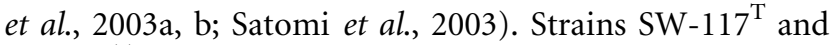
$\mathrm{SW}-120^{\mathrm{T}}$ have respiratory lipoquinone patterns similar to those of Shewanella species, containing Q-7 and Q-8 as the predominant ubiquinones. Menaquinone detected in strain $\mathrm{SW}-117^{\mathrm{T}}$ and $\mathrm{SW}-120^{\mathrm{T}}$ has also been detected in some Shewanella species together with ubiquinones, although their compositions are variable for different strains or species (Nogi et al., 1998; Venkateswaran et al., 1999; Bozal et al., 2002).

Strains SW $-117^{\mathrm{T}}$ and SW $-120^{\mathrm{T}}$ have approximately $39 \mathrm{bp}$ $(2 \cdot 6 \%)$ differences between their 16S rRNA gene sequences.

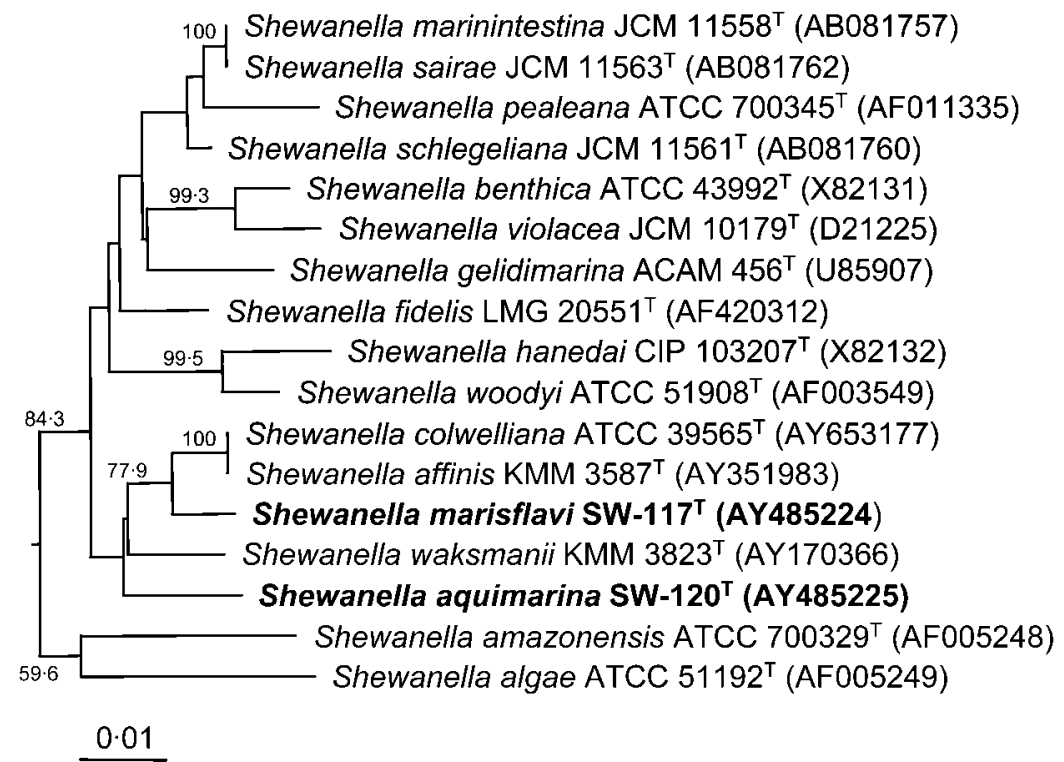

Fig. 1. Neighbour-joining tree showing the phylogenetic positions of strains $\mathrm{SW}-117^{\top}$ and $\mathrm{SW}-120^{\top}$ and representatives of related taxa based on 16S rRNA gene sequences. Bootstrap values (expressed as percentages of 1000 replications) greater than $50 \%$ are shown at the branch points. Bar, 0.01 substitution per nucleotide position. The tree from which Fig. 1 was taken is available as supplementary material in IJSEM Online. 
Both strains are considered to be members of different species based on DNA-DNA hybridization data, together with differences in the DNA G $+\mathrm{C}$ contents and in their phenotypic properties, including, among others, growth at $4{ }^{\circ} \mathrm{C}$ and in the absence of $\mathrm{NaCl}$, and starch hydrolysis (Table 1). Strains SW- $117^{\mathrm{T}}$ and $\mathrm{SW}-120^{\mathrm{T}}$ are differentiated from phylogenetically related Shewanella species by some physiological and biochemical characteristics, such as temperature for growth, $\mathrm{NaCl}$ tolerance and the ability to utilize certain substrates (Table 1 and Table S1 in IJSEM Online). Strain SW- $117^{\mathrm{T}}$ exhibited $16 \mathrm{~S}$ rRNA gene sequence similarity levels of less than $96 \cdot 3 \%$ to the type strains of other Shewanella species except $S$. affinis, S. colwelliana, $S$. waksmanii, S. marinintestina, S. sairae and S. schlegeliana. Levels of DNA-DNA relatedness between strains SW- $117^{\mathrm{T}}$ and SW- $-120^{\mathrm{T}}$ and the type strains of some phylogenetically related Shewanella species are far below the threshold value $(70 \%)$ suggested for species delineation in current bacterial systematics (Wayne et al., 1987). Levels of $16 \mathrm{~S}$ rRNA gene sequence similarity $(92 \cdot 4-97 \cdot 0 \%)$ between strain SW $-120^{\mathrm{T}}$ and the type strains of Shewanella species are low enough to categorize strain SW- $120^{\mathrm{T}}$ as representing a species distinct from recognized Shewanella species (Stackebrandt \& Goebel, 1994). Therefore, in view of the combined phenotypic, chemotaxonomic and phylogenetic data, together with genomic distinctiveness, strains SW$117^{\mathrm{T}}$ and SW- $-120^{\mathrm{T}}$ should be placed in the genus Shewanella as two distinct novel species, for which the names Shewanella marisflavi sp. nov. and Shewanella aquimarina sp. nov. are proposed, respectively.

\section{Description of Shewanella marisflavi sp. nov.}

Shewanella marisflavi (ma.ris.fla'vi. L. gen. neut. n. maris of the sea; L. masc. adj. flavus yellow; N.L. gen. n. marisflavi of the Yellow Sea).

Cells are straight rods, $0 \cdot 8-1 \cdot 1 \times 2 \cdot 0-3 \cdot 5 \mu \mathrm{m}$ on MA. Nonspore-forming. Motile by means of a single polar flagellum. Colonies are smooth, glistening, circular, flat to slightly raised, light brown in colour and $2 \cdot 0-4 \cdot 0 \mathrm{~mm}$ in diameter after 3 days incubation at $30^{\circ} \mathrm{C}$ on MA. Growth occurs at 4 and $42{ }^{\circ} \mathrm{C}$, but not above $43{ }^{\circ} \mathrm{C}$. Growth is observed at $\mathrm{pH} 5 \cdot 0$, but not at $\mathrm{pH} 4 \cdot 5$. Optimal growth occurs in the presence of $2-3 \% \mathrm{NaCl}$. No growth occurs in the presence of more than $9 \% \mathrm{NaCl}$. Growth occurs under anaerobic conditions on MA. Casein, tyrosine and Tween 80 are hydrolysed. Aesculin, hypoxanthine, urea, xanthine and xylan (birch wool) are not hydrolysed. When assayed with the API ZYM system, alkaline phosphatase, esterase (C4), esterase lipase (C8), $\alpha$-chymotrypsin, acid phosphatase, naphthol-AS-BI-phosphohydrolase and $N$-acetyl- $\beta$ glucosaminidase are present and leucine arylamidase is weakly present, but lipase (C14), valine arylamidase, cystine arylamidase, trypsin, $\alpha$-galactosidase, $\beta$-galactosidase, $\beta$ glucuronidase, $\alpha$-glucosidase, $\beta$-glucosidase, $\alpha$-mannosidase and $\alpha$-fucosidase are absent. Acid is produced from D-cellobiose, D-glucose, maltose and D-ribose. Acid is not produced from L-arabinose, D-fructose, D-galactose, lactose, D-mannose, D-melezitose, melibiose, D-raffinose, L-rhamnose, stachyose, sucrose, D-trehalose, D-xylose, adonitol, D-mannitol, myo-inositol or D-sorbitol. Both menaquinones and ubiquinones are present; the predominant menaquinone is MK-7 and the predominant ubiquinones are Q-7 and Q-8. The major fatty acid is iso- $\mathrm{C}_{15: 0}$. The DNA G $+\mathrm{C}$ content is $51 \mathrm{~mol} \%$ (determined by HPLC). Other phenotypic characteristics are given in Table 1.

The type strain $\left(\mathrm{SW}-117^{\mathrm{T}}=\mathrm{KCCM} 41822^{\mathrm{T}}=\mathrm{JCM} 12192^{\mathrm{T}}\right)$ was isolated from sea water of the Yellow Sea in Korea.

\section{Description of Shewanella aquimarina sp. nov.}

Shewanella aquimarina (a.qui.ma.ri'na. L. n. aqua water; L. adj. marinus of the sea; N.L. fem. adj. aquimarina pertaining to sea water).

Cells are straight rods, $0 \cdot 6-0 \cdot 9 \times 2 \cdot 0-4 \cdot 0 \mu \mathrm{m}$ on MA. Nonspore-forming. Motile by means of a single polar flagellum. Colonies are smooth, glistening, circular, flat to slightly raised, light brown in colour and $2 \cdot 0-4 \cdot 0 \mathrm{~mm}$ in diameter after 3 days incubation at $30^{\circ} \mathrm{C}$ on MA. Growth occurs at 10 and $42^{\circ} \mathrm{C}$, but not at $4{ }^{\circ} \mathrm{C}$ or above $43^{\circ} \mathrm{C}$. Growth is observed at $\mathrm{pH} 5 \cdot 0$, but not at $\mathrm{pH} 4 \cdot 5$. Optimal growth occurs in the presence of $2-3 \% \mathrm{NaCl}$. No growth occurs in the presence of more than $9 \% \mathrm{NaCl}$. Growth occurs under anaerobic conditions on MA. Casein, tyrosine and Tween 80 are hydrolysed. Aesculin, hypoxanthine, urea, xanthine and xylan (birch wool) are not hydrolysed. When assayed with the API ZYM system, alkaline phosphatase, esterase (C4), esterase lipase (C8), $\alpha$-chymotrypsin, acid phosphatase, naphthol-AS-BI-phosphohydrolase and $N$-acetyl- $\beta$ glucosaminidase are present and leucine arylamidase is weakly present, but lipase (C14), valine arylamidase, cystine arylamidase, trypsin, $\alpha$-galactosidase, $\beta$-galactosidase, $\beta$ glucuronidase, $\alpha$-glucosidase, $\beta$-glucosidase, $\alpha$-mannosidase and $\alpha$-fucosidase are absent. Acid is produced from Dribose. Acid is not produced from L-arabinose, D-cellobiose, D-fructose, D-galactose, D-glucose, lactose, maltose, Dmannose, D-melezitose, melibiose, D-raffinose, L-rhamnose, stachyose, sucrose, D-trehalose, D-xylose, adonitol, Dmannitol, myo-inositol or D-sorbitol. Both menaquinones and ubiquinones are present; the predominant menaquinone is MK-7 and the predominant ubiquinones are Q-7 and Q-8. The major fatty acid is iso- $\mathrm{C}_{15: 0}$. The DNA $\mathrm{G}+\mathrm{C}$ content is $54 \mathrm{~mol} \%$ (determined by HPLC). Other phenotypic characteristics are given in Table 1.

The type strain $\left(\mathrm{SW}-120^{\mathrm{T}}=\mathrm{KCCM} 41821^{\mathrm{T}}=\mathrm{JCM} 12193^{\mathrm{T}}\right)$ was isolated from sea water of the Yellow Sea in Korea.

\section{Acknowledgements}

This work was supported by the 21C Frontier program of Microbial Genomics and Applications (grant MG02-0401-001-1-0-0) from the Ministry of Science and Technology (MOST) of the Republic of Korea. We are grateful to Professor Elena P. Ivanova for providing S. affinis $\mathrm{KMM} 3587^{\mathrm{T}}$ and S. waksmanii KMM $3823^{\mathrm{T}}$. 


\section{References}

Anzai, Y., Kim, H., Park, J.-Y., Wakabayashi, H. \& Oyaizu, H. (2000). Phylogenetic affiliation of the pseudomonads based on 16S rRNA sequence. Int J Syst Evol Microbiol 50, 1563-1589.

Baumann, L. \& Baumann, P. (1981). The marine Gram-negative eubacteria; genera Photobacterium, Beneckea, Alteromonas, Pseudomonas, and Alcaligenes. In The Prokaryotes. A Handbook on Habitats, Isolation, and Identification of Bacteria, pp. 1302-1330. Edited by M. P. Starr, H. Stolp, H. G. Trüper, A. Balows \& H. G. Schlegel. Berlin: Springer.

Bowman, J. P., McCammon, S. A., Nichols, D. S., Skerratt, J. H., Rea, S. M., Nichols, P. D. \& McMeekin, T. A. (1997). Shewanella gelidimarina sp. nov. and Shewanella frigidimarina sp. nov., novel Antarctic species with the ability to produce eicosapentaenoic acid $(20: 5 \omega 3)$ and grow anaerobically by dissimilatory Fe(III) reduction. Int J Syst Bacteriol 47, 1040-1047.

Bozal, N., Montes, M. J., Tudela, E., Jiménez, F. \& Guinea, J. (2002). Shewanella frigidimarina and Shewanella livingstonensis sp. nov. isolated from Antarctic coastal areas. Int J Syst Evol Microbiol 52, 195-205.

Brink, A. J., van Straten, A. \& van Rensburg, A. J. (1995). Shewanella (Pseudomonas) putrefaciens bacteremia. Clin Infect Dis 20, 1327-1332.

Bruns, A., Rohde, M. \& Berthe-Corti, L. (2001). Muricauda ruestringensis gen. nov., sp. nov., a facultatively anaerobic, appendaged bacterium from German North Sea intertidal sediment. Int J Syst Evol Microbiol 51, 1997-2006.

Cowan, S. T. \& Steel, K. J. (1965). Manual for the Identification of Medical Bacteria. London: Cambridge University Press.

Ezaki, T., Hashimoto, Y. \& Yabuuchi, E. (1989). Fluorometric deoxyribonucleic acid-deoxyribonucleic acid hybridization in microdilution wells as an alternative to membrane filter hybridization in which radioisotopes are used to determine genetic relatedness among bacterial strains. Int J Syst Bacteriol 39, 224-229.

Ivanova, E. P., Sawabe, T., Gorshkova, N. M., Svetashev, V. I., Mikhailov, V. V., Nicolau, D. V. \& Christen, R. (2001). Shewanella japonica sp. nov. Int J Syst Evol Microbiol 51, 1027-1033.

Ivanova, E. P., Sawabe, T., Hayashi, K., Gorshkova, N. M., Zhukova, N. V., Nedashkovskaya, O. I., Mikhailov, V. V., Nicolau, D. V. \& Christen, R. (2003a). Shewanella fidelis sp. nov., isolated from sediments and sea water. Int J Syst Evol Microbiol 53, 577-582.

Ivanova, E. P., Nedashkovskaya, O. I., Zhukova, N. V., Nicolau, D. V., Christen, R. \& Mikhailov, V. V. (2003b). Shewanella waksmanii sp. nov., isolated from a sipuncula (Phascolosoma japonicum). Int J Syst Evol Microbiol 53, 1471-1477.

Ivanova, E. P., Nedashkovskaya, O. I., Sawabe, T., Zhukova, N. V., Frolova, G. M., Nicolau, D. V., Mikhailov, V. V. \& Bowman, J. P. (2004). Shewanella affinis sp. nov., isolated from marine invertebrates. Int J Syst Evol Microbiol 54, 1089-1093.

Komagata, K. \& Suzuki, K.-I. (1987). Lipids and cell-wall analysis in bacterial systematics. Methods Microbiol 19, 161-203.

Lanyi, B. (1987). Classical and rapid identification methods for medically important bacteria. Methods Microbiol 19, 1-67.

Leifson, E. (1963). Determination of carbohydrate metabolism of marine bacteria. J Bacteriol 85, 1183-1184.

Levring, T. (1946). Some culture experiments with Ulva and artificial seawater. K Fysiogr Sällsk Lund Förh 16, 45-56.
MacDonell, M. T. \& Colwell, R. R. (1985). Phylogeny of the Vibrionaceae, and recommendation for two new genera, Listonella and Shewanella. Syst Appl Microbiol 6, 171-182.

Myers, C. R. \& Nealson, K. H. (1988). Bacterial manganese reduction and growth with manganese oxide as the sole electron acceptor. Science 240, 1319-1321.

Nealson, K. H., Myers, C. R. \& Wimpee, B. (1991). Isolation and identification of manganese-reducing bacteria, and estimates of microbial Mn(IV)-reducing potential in the Black Sea. Deep Sea Res 38, Suppl 2, S907-S920.

Nogi, Y., Kato, C. \& Horikoshi, K. (1998). Taxonomic studies of deep-sea barophilic Shewanella strains and description of Shewanella violacea sp. nov. Arch Microbiol 170, 331-338.

Nozue, H., Hayashi, T., Hashimoto, Y., Ezaki, T., Hamasaki, K., Ohwada, K. \& Terawaki, Y. (1992). Isolation and characterization of Shewanella alga from human clinical specimens and emendation of the description of S. alga Simidu et al. 1990, 335. Int J Syst Bacteriol 42, 628-634.

Sasser, M. (1990). Identification of bacteria by gas chromatography of cellular fatty acids. Technical Note 101. Newark, DE: MIDI.

Satomi, M., Oikawa, H. \& Yano, Y. (2003). Shewanella marinintestina sp. nov., Shewanella schlegeliana sp. nov. and Shewanella sairae sp. nov., novel eicosapentaenoic-acid-producing marine bacteria isolated from sea-animal intestines. Int J Syst Evol Microbiol 53, 491-499.

Semple, K. M. \& Westlake, D. W. S. (1987). Characterization of ironreducing Alteromonas putrefaciens strains from oil field fluids. Can J Microbiol 33, 366-371.

Stackebrandt, E. \& Goebel, B. M. (1994). Taxonomic note: a place for DNA-DNA reassociation and 16S rRNA sequence analysis in the present species definition in bacteriology. Int J Syst Bacteriol 44, 846-849.

Tamaoka, J. \& Komagata, K. (1984). Determination of DNA base composition by reverse-phase high-performance liquid chromatography. FEMS Microbiol Lett 25, 125-128.

Venkateswaran, K., Moser, D. P., Dollhopf, M. E. \& 10 other authors (1999). Polyphasic taxonomy of the genus Shewanella and description of Shewanella oneidensis sp. nov. Int J Syst Bacteriol 49, 705-724.

Wayne, L. G., Brenner, D. J., Colwell, R. R. \& 9 other authors (1987). International Committee on Systematic Bacteriology. Report of the ad hoc committee on reconciliation of approaches to bacterial systematics. Int J Syst Bacteriol 37, 463-464.

Weiner, R. M., Coyne, V. E., Brayton, P., West, P. \& Raiken, S. F. (1988). Alteromonas colwelliana sp. nov., an isolate from oyster habitats. Int J Syst Bacteriol 38, 240-244.

Yoon, J.-H., Kim, H., Kim, S.-B., Kim, H.-J., Kim, W. Y., Lee, S. T., Goodfellow, M. \& Park, Y.-H. (1996). Identification of Saccharomonospora strains by the use of genomic DNA fragments and rRNA gene probes. Int J Syst Bacteriol 46, 502-505.

Yoon, J.-H., Lee, S. T. \& Park, Y.-H. (1998). Inter- and intraspecific phylogenetic analysis of the genus Nocardioides and related taxa based on 16S rDNA sequences. Int J Syst Bacteriol 48, 187-194.

Yoon, J.-H., Kim, I.-G., Shin, D.-Y., Kang, K. H. \& Park, Y.-H. (2003). Microbulbifer salipaludis sp. nov., a moderate halophile isolated from a Korean salt marsh. Int J Syst Evol Microbiol 53, $53-57$. 